\title{
Measuring Think Tank Influence Using Quantitative Text Analysis
}

\author{
Sun Zhiru ${ }^{1}$ Zhang Zhiqiang ${ }^{2}$ \\ ${ }^{1}$ Center for International Agricultural Economics, Heilongjiang Academy of \\ Agricultural Science \\ ${ }^{2}$ Lanzhou Branch of Natinonal Science Library, Chinese Academy of Science
}

\begin{abstract}
Measuring think tank influence is crucial to explain policy outcomes and to assess the action of think tank. This article therefore presents a new method for measuring this type of influence, drawing on quantitative text analysis. By comparing think tanks' policy position with the final policy output, one can assess the preference realization of think tanks in the decision-making process. The method is illustrated by a case regarding the influence of environment think tanks on Obama Government.
\end{abstract}

Keywords: think tank; quantitative text analysis; influence; Wordfish

\section{Introduction}

Analyzing think tank influence should be of central concern to scholars and journalists studying so-called think tank phenomenon. However, despite their growing importance in the policy-making process, only few researchers have in fact measure the influence or impact of think tanks on policy-making. So far, several quantitative assessment was often used to measure the think tank influence: media citation $^{[1]}$, congressional testimony ${ }^{[2]}$, assessing attributed influence ${ }^{[3]}$, web-based impact ${ }^{[4]}$.

In this research, we will present a new quantitative method for measuring think tank influence, drawing on quantitative text analysis. By comparing think tanks' policy position with the final policy output, we can gauge the degree of preference attainment.

\section{Description for method}

Influence is generally understood as an actor's ability to shape a decision in line with her preferences, or, in other words, 'a causal relation between the preferences of an actor regarding an outcome and the outcome itself ${ }^{[5]}$. The method to be presented in this paper is to quantify the extent that a think tank's preferences are realized as a consequence of decision making. In this method, the outcomes of political processes are compared with the ideal points of actors. Several studies have applied this method to the study of interest group influence in the $\mathrm{EU}^{[6-8]}$. They focused on some specific issues, coded whether or not an outcome reflectd the preferences of the group active on this issue. Then they can draw conclusions on which type of actor was more or less influential.

However, think tanks all annouce their research is independent and subjective. So we drawn on multi-issues and measured on an ordinal scale of: attained none of their objective ( 0 point), attained some of their objective( 0.5 point $)$, fully attained their goal( 1 point).

When using this measurement of the influence, it is difficult to control the salience that an issue has for think tank ${ }^{[9]}$, 
and also there is a smaller impact of alternative causes: (a) One or more other actors are partly or totally responsible for the preference realiztion. (b) External factors partly or totally cause its preference realization. (c) Its preference realization is part of an ongoing autonomous development ${ }^{[10]}$.

Although there are these limits, this method can help us recognize the think tank's success in policy shift and the extent their success, i.e. the probability. A random sample of issues ${ }^{[7]}$ and large number of cases ${ }^{[6]}$ can help filter these alternative factors. Then the success of think tank can take place of its influence approximatively.

Textual data is arguably the most widely available source of evidence on political processes. Content analysis was developed to make systematic use of this rich data source. The articles published by think tanks and political documents have a great potential to reveal informaiton about the policy positions of their authors: texts can be analysed as many times as one wish and they provide information about policy positions at a specific point in time.

Currently, there are three primary methods for extract position from policy text: expert surveys, hand coding and computer-based content analysis. Text analysis software WORDSCORES $S^{[11]}$ and Wordfish $^{[12,13]}$ are all proved to be reliable and with high degree of validity.

\section{Quantifying influence research de- sign}

\subsection{Text analysis}

In this section, we explain in detail which texts I used and specific steps for the case study. We will take American enviroment think tanks' influence as an example.

The think tank samples come from 'Top 10 Environment Think Tanks' in
The Global "Go-To Think Tanks" issued in 2009 and 2010. There are 11 think tanks from USA were selected :

Table 1: 11 environment think tanks of USA

\begin{tabular}{|c|c|}
\hline & Institute \\
\hline 1 & $\begin{array}{l}\text { Belfer Center for Science and Internation- } \\
\text { al Affairs, Kennedy School of Govern- } \\
\text { ment }\end{array}$ \\
\hline 2 & Brookings Institution \\
\hline 3 & $\begin{array}{l}\text { Carnegie Endowment for International } \\
\text { Peace }\end{array}$ \\
\hline 4 & Cato Institute \\
\hline 5 & $\begin{array}{l}\text { Freeman Spogli Institute Program on } \\
\text { Energy and Sustainable Development, } \\
\text { Stanford University }\end{array}$ \\
\hline 6 & Heritage Foundation \\
\hline 7 & Pew Center on Global Climate Change \\
\hline 8 & RAND Corporation \\
\hline 9 & Resources for the Future(RFF) \\
\hline 10 & World Resources Institute(WRI) \\
\hline 11 & Worldwatch Institute \\
\hline
\end{tabular}

During government transition period, think tanks often exert more influence, and the policy advises are often adopted more easily. So at first, we collected 609 articles published between 2008 and 2009 by these 11 institutions including Commentary \& Analysis, Policy Research, Testimony, Book, Working Paper, Report, Journal Article, Newpaper Article, Web Page; also I collected 5 policy documents issued since Jan. 2008 to Apri. 2009 while Barack Obama won the 2008 presidential election. The policy documents are as followed:

- American Recovery and Reinvestment Act of 2009

- Remarks by the President on Jobs, Energy Independence, and Climate Change

- Memorandum for the Secretary of Energy: Appliance Efficiency Standards

- Making Strides, Improving Standards 
- Remarks by the Presideng on Clean Energy

Before filtering these texts, we structured them by manual processing. Input the information to Endnote, then using Endnote transform these information into the type RefViz can recognize. Due to RefViz can only analyze the title and abstract, to reflect the content we alter the title of policy documents. Also using 'topic tool' of RefViz we move 'environment' from column 'minor topic' to 'major topic', and move 'policy' from 'descriptive terms' to 'minor topic'. RefViz clustered these text data into 24 groups and filtered 207 articles relevant to these 5 policy documents. Then we downloaded their fulltext and extracted the policy position with Wordfish.

The influence can be measured as followed: If the position value of think tank text $i\left(P_{i}\right)$ and the position value of policy text $j\left(P_{j}\right)$ at the same side, and $P_{i}>P_{\mathrm{j}}$, then let the degree of preference realization of text $i\left(P A_{i}\right)$ equal to $1 / 2$, or 1 . If $P_{i}$ and $P_{j}$ at the diffqqcerent sides, let $P A_{i}$ equal to 0 . Add up $P A_{i}$ together, and we will get the degree of think tank preference realization on one issue, that is a approximate measurement of think tank influence. Calculation formula is as followed:

$$
\begin{aligned}
& P I \approx \sum_{i=1}^{n} P A_{i} \\
& P A_{i}= \begin{cases}0 & P i \times P j<0 \\
1 / 2 & P i \times P j \geq 0, P i-P j>0 \\
1 & P i \times P j \geq 0, P i-P j \leq 0\end{cases}
\end{aligned}
$$

Then we abtain the following result for think tank influence measurement:
Table 2: Total points for 11 institutes influence

\begin{tabular}{lll}
\hline Rank & institute & $\begin{array}{l}\text { Total } \\
\text { points }\end{array}$ \\
\hline 1 & Heritage Foundation & 24.5 \\
2 & Brookings Institution & 20 \\
3 & Belfer Center & 17 \\
4 & RFF & 15 \\
5 & Cato Institute & 12.5 \\
6 & WRI & 8 \\
7 & Freeman Spogli Institute & 5 \\
8 & RAND Corporation & 5 \\
9 & Worldwatch Institute & 4.5 \\
10 & Carnegie Endowment for & 2.5 \\
11 & International Peace & 1.5 \\
\hline
\end{tabular}

\subsection{Qualitive analysis}

Because of the many pitfalls in this stage of the research, we have to check this method by means of qualitative material. The top 2 institutes were tested.

Conservative Heritage Foundation did not agree to take radical measures on envrionmental policy of Obama. Heritage's Center for Data Analysis (CDA) ran an econometric analysis of Waxman-Markey that exposed a host of damages the multi-trillion-dollar plan would inflict upon the American economy. Expert David Kreutzer, and Heritage environmental analyst Ben Lieberman presented testimony before two House and two Senate committees. As knowledge of Heritage's clear, credible analyses spread, so did reservations about pursuing a cap-and-trade policy. On the Hill, moderates joined conservatives in expressing grave reservations about the approach ${ }^{[14]}$.

Brookings sided with Obama on environment issues. Brookings' impact especially resounded in this presidential transition year. During the 77 days from the election to the Inauguration, Brookings experts offered 12 'Memos to the President' on policy priorities, starting with governance and climate change and expanding across the spectrum of domestic 
and global challenges ${ }^{[15]}$. Some suggestions on renewable energy and conservation, federal-state partnership on energy infrastructure and standards are all adopted by Obama Government.

\section{Conclusion}

The aim of this article was to illustrate the usefulness of text analysis for the measurement of think tank influence. Think tank influence can be measured by comparing the policy preferences of think tanks with the final policy output. This approach is promising since it provides an objective measurement, and also is a black-boxing meathod which can cover all channels of influence and can be applied to a large number of cases. But at the same time problematic that it dose not make it clear through which channels influence is exerted. The policy-making process consists of several stages including agenda setting, policy formulation, and policy implementation ${ }^{[16]}$. The method focuses on the involvement of think tanks during first two stages.

\section{References}

[1] D.E. Abelson: "Think Tanks and U.S. Foreign Policy: An Historical Perspective". U.S. Foreign Policy Agenda pp.9-12, 2002.

[2] D.E. Abelson: "Do think tanks matter?: Assessing the Impact of Public Policy Institutes". New York: McGill-Queen's University Press Montreal; 2002.

[3] J.G. March: "An introduction to the theory and measurement of influence". The American Political Science Review pp.431-451, 1955.

[4] K. McNutt, G. Marchildon: "Think Tanks and the Web: Measuring Visibility and Influence". Canadian Public Policy pp.219-236, 2009.
[5] J.H. Nagel: "The Descriptive Analysis of Power". London: Yale University Press New Haven;pp.29, 1975.

[6] G. Schneider, K. Baltz: "The power of specialization: how interest groups influence EU legislation". Rivista di Politica Economica pp.253-288, 2003.

[7] C. Mahoney: "Lobbying success in the United States and the European Union". Journal of Public Policy pp.35-56, 2007.

[8] A. Dür: "Bringing Economic Interests Back Into the Study of EU Trade Policy-Making". British Journal of Politics and International Relations pp. 27, 2008.

[9] A. Dür: "Measuring Interest Group Influence in the EU: A Note on Methodology". European Union Politics pp.559, 2008.

[10] P. Verschuren, B. Arts: "Quantifying influence in complex decision making by means of paired comparisons". Quality and Quantity pp.495-516, 2005.

[11] http://www.wordscores.com/

[12] J.B. Slapin, S.-O. Proksch: "A Scaling Model for Estimating Time-Series Party Positions from Texts". American Journal of Political Science pp.705-722, 2008.

[13] S.O. Proksch, J.B. Slapin: WORDFISH: Scaling Software for Estimating Political Positions from Texts. Version $1.3 \quad$ (22 Janurary 2009 ), 2009.

[14] Heritage: The Heritage Foundation 2009 Annual Report. Washington D.C.: Heritage Foundation; 2009.

[15] Brookings: Brookings Annual Report 2009. Washingtong ,DC: Brookings Institution; 2009.

[16] J.W. Kingdon: "Agendas, Alternatives, and Public Policies ". Boston: Little brown, 1984. 